\title{
Комплексна оцінка та корекція функціонального стану і резервних можливостей організму спортсменів
}

\author{
УДК: 612.08.796-051 \\ О. Є. Дорофєєва
}

ДЗ «Дніпропетровська медична академія МОЗ України», Дніпропетровськ, Україна

Резюме. У статті розглянуто питання оцінки функціонального стану спортсменів, ранніх критеріїв напруження адаптаційних механізмів і запропоновано реабілітаційну терапію. Метою дослідження є оцінка функціонального стану спортсменів, виявлення напруження адаптаційних механізмів, яке є проявом можливого переходу в наступну фазу - фазу виснаження і формування у спортсменів патологічних станів і захворювань, а також своєчасне проведення корекції. Методи дослідження: аналіз сучасної науково-методичної літератури; клінічні, інструментальні та лабораторні обстеження; методи математичної статистики. Результати дослідження. Ознаки напруження адаптації за даними ЕКГ виявлено в стані спокою у 13,6 \% спортсменів, після навантаження - у 20,8 \%, за даними варіаційної пульсометрії (ВПМ) - у 22,8 \%, за даними тесту $\mathrm{PWC}_{170}$ - у 7,0 \%, хоча спортивні результати протягом року погіршувалися у 39,1 \%. Це підтверджує думку про те, що для оцінки адаптаційних можливостей спортсменів і своєчасного проведення корекції слід використовувати не лише дані ЕКГ, ВПМ та ергометрії, але й дані біохімічного й імунологічного досліджень. У всіх спортсменів виявлено модифікацію метаболізму та імунного статусу, яка була більш виражена у спортсменів з напруженням адаптації. Для корекції напруження адаптаційних механізмів усі обстежені спортсмени отримували планову фармакологічну підтримку два рази на рік (восени і навесні), що позитивно вплинуло на адаптацію до фізичних навантажень. Висновки. У роботі доведено необхідність урахування критеріїв напруження адаптаційних механізмів для своєчасного призначення реабілітаційних заходів у кваліфікованих спортсменів. Запропоновано планову фармакологічну підтримку, яка дозволила поліпшити стан здоров'я спортсменів, сприяла зниженню частоти захворюваності, тривалості захворювань і пропусків тренувальних днів, що забезпечило планомірну, якісну підготовку спортсменів до успішних виступів на змаганнях.

Ключові слова: адаптація, корекція, механізми, напруження, спортсмени, функціональний стан.

Резюме. В статье рассмотрены вопросы оценки функционального состояния спортсменов, ранних критериев напряжения адаптационных механизмов и предложена реабилитационная терапия. Цель исследования - оценка функционального состояния спортсменов, выявление напряжения адаптационных механизмов, что отражает возможность перехода в следующую фазу - фазу истощения и формирования у спортсменов патологических состояний и заболеваний, а также своевременного проведения коррекции. Методы исследования: анализ современной научно-методической литературы; клинические, инструментальные и лабораторные исследования; методы математической статистики. Результаты исследования. Признаки напряжения адаптации по данным ЭКГ обнаружены в состоянии покоя у 13,6 \% спортсменов, после нагрузки - у 20,8 \%, по данным вариационной пульсометрии (ВПМ) у 22,8 \%, по данным теста $\mathrm{PWC}_{170}$ - у 7,0 \%, хотя спортивные результаты в течение года ухудшались у 39,1%. Это подтверждает мнение о том, что при оценке адаптационных возможностей спортсменов и для своевременного проведения коррекции следует использовать не только данные ЭКГ, ВПМ и эргометрии, но и данные биохимического и иммунологического исследований. У спортсменов обнаружена модификация метаболизма и иммунного статуса, более выраженная у спортсменов с напряжением адаптации. Для коррекции напряжения адаптационных механизмов все обследованные спортсмены получали плановую фармакологическую поддержку два раза в год (осенью и весной), что положительно повлияло на адаптацию к физическим нагрузкам. Выводы. В работе доказана необходимость учета критериев напряжения адаптационных механизмов для своевременного назначения реабилитационных мероприятий у квалифицированных спортсменов. Предложена 
плановая фармакологическая поддержка, которая позволила улучшить состояние здоровья спортсменов, способствовала снижению частоты заболеваемости, продолжительности заболеваний и пропусков тренировочных дней, что обеспечило планомерную, качественную подготовку спортсменов к успешным выступлениям на соревнованиях.

Ключевые слова: адаптация, коррекция, механизмы, напряжение, спортсмены, функциональное состояние.

Abstract. The paper deals with evaluation of the functional state of athletes, early criteria of adaptation mechanism tension and suggests the rehabilitation therapy. Objective of study: assessment of the functional state of athletes, identifying the tension of adaptation mechanisms, which reflects the possibility of transition to the next phase - the phase of exhaustion and formation of pathological conditions and diseases in athletes, as well as the timely implementation of the correction. Methods: analysis of the current scientific literature; clinical, instrumental and laboratory investigations; methods of mathematical statistics. Results. Signs of adaptation tension according to ECG data were found in rest in $13.6 \%$ of athletes and after exercise - in $20.8 \%$, according to those of variation pulsometry (VPM) - in $22.8 \%$, according to PWC $_{170}$ test - in $7.0 \%$ although athletic performance was deteriorating in $39.1 \%$ within a year. This confirms the view that, in assessing adaptation capacities of the athletes and for timely correction making not only the data of ECG, VPM and ergometry, but also those of biochemical and immunologica studies should be used. A modification of the metabolism and immune status has been revealed in athletes, which was more pronounced among those with adaptation tension. In order to correct the adaptive mechanisms tension, all surveyed athletes received routine pharmacological support twice a year (fall and spring), which has a positive effect on adaptation to physical loads. Conclusions. The necessity of taking into account the criteria adaptation mechanisms tension for the timely appointment of rehabilitation measures for qualified athletes has been proved. A routine pharmacological support, which improved the state of the health of athletes, helped to reduce the incidence rate, duration of disease and omission of training days has been suggested, which provided a systematic, qualitative preparation of athletes for successful performances in the competitions.

Keywords: adaptation, correction, mechanisms, tension, athletes, functional state.

Постановка проблеми дослідження. Аналіз останніх досліджень і публікацій. Зростання результатів змагань у світовій практиці здійснюється здебільшого за рахунок інтенсифікації тренувального процесу. Значні фрізичні навантаження як стресовий чинник призводять до напруження адаптаційних механізмів, при порушенні яких не лише погіршуються спортивні результати, але і формуються патологічні зміни, що призводять до тяжких захворювань, перетренованості i, в окремих випадках, до раптової смерті (РС). Однією з головних причин РС є патологія серцево-судинної системи, яка зустрічається у більш ніж $90 \%$ випадків $[17,18]$.

Зростання частоти РС спортсменів, у тому числі юних, створює передумови для активізації профрілактичного напряму спортивної медицини, спрямованого на ранню діагностику захворювань, що призводять до РС у спорті, і кваліфрікованого лікарського контролю за тренувальним процесом [6, 10, 13, 19].

3 метою профілактики РС у спорті в різних країнах було створено реєстр і запропоновано декілька протоколів для профрілактики РС (американський, європейський і італійський). В Америці група експертів American Heart Association назвала його «12 кроків». Це дозволило значно знизити показник РС у спорті в Америці та європейських країнах $[12,15,16]$.
На жаль, в Україні відсутній національний реєстр випадків РС у спорті. Вперше в Україні протокол обстеження для профрілактики РС було розроблено і запропоновано кафедрою спортивної медицини Дніпропетровської медичної академії, який, на відміну від попередніх, враховує генетичні особливості і генетичні маркери осіб, які займаються фрізичною культурою і спортом [7].

У зв'язку з вищевикладеним, комплексна оцінка фрункціонального стану та резервних можливостей, оперативний контроль за вираженими адаптаційними змінами у спортсменів потрібні не лише для керування тренувальним процесом i прогнозування спортивних результатів, але і для запобігання захворюванням, своєчасної корекції медико-біологічними засобами та збереження здоров'я спортсменів [2, 3, 5, 8].

3 цією метою спортивні лікарі та фрізіологи оцінюють фрункціональний стан серцево-судинної і дихальної систем, ЦНС, периферичної та вегетативної нервових систем, сенсорної системи, апарату нервово-м'язового проведення 3 використанням функціональних проб, що дають поглиблену характеристику зазначених фрізіологічних систем [6, 9, 10].

У практиці функціональної діагностики на цьому етапі проводяться такі дослідження:

- клінічні - оцінка фрізичного розвитку (соматометрія, соматоскопія) i генетично детер- 
мінованих чинників - для виявлення ознак дисплазії сполучної тканини (ДСТ) та ін.;

- лабораторні - біохімічні, імунологічні, генетичні, інвазивна оцінка композиції скелетних м'язів тощо;

- інструментальні - ЕКГ, ЕхоКГ, ФКГ, спірометрія, спірографрія, РЕГ, варіаційна пульсометрія, ергометрія, електроміографрія, електронейроміографрія, стабілографрія та ін.;

- психофрізіологічні - ергографрія, реєстрація шкірно-гальванічної реакції, критична частота світлових мерехтінь (КЧСМ), тест Люшера, теппінг-тест тощо.

Вибір найбільш зручних та інформативних методів проводиться після узгодження з тренером і спортсменом. Вони залежать від поставлених завдань, від специфіки виду спорту (циклічні, ациклічні, швидкісно-силові, єдиноборства та ін.), який висуває неоднакові вимоги до різних систем, від тренувального періоду та ін.

Зарубіжні вчені з 1970-х років використовують високовартісну інвазивну оцінку композиції скелетних м'язів, а з 1980-х років досліджують генетичні маркери (генотип професійних спортсменів). На сьогодні відомо 215 генетичних маркерів людини, пов'язаних з руховою активністю. Серед них слід виділити 120 генів, пов'язаних 3 елітним статусом спортсмена, поліморфізм яких асоційований із розвитком і проявом фрізичних якостей людини (77 - у видах спорту з переважним розвитком витривалості і 43 - у швидкісно-силових видах спорту). Проте основним питанням $€$ визначення генетичного профілю, який суттєво впливає на статус елітного спортсмена $[1,3,4,14]$.

Більшість запропонованих зарубіжних методик хоча й інформативні, але високовартісні, потребують використання спеціального обладнання, наявності спеціально підготовленого персоналу, малодоступні і головне - є додатковими.

Для динамічної оперативної оцінки і контролю, доклінічної експрес-діагностики різних відхилень не лише в лабораторних умовах, але й під час тренувального процесу, необхідне використання доступних та інформативних методик, що в даний момент є метою багатьох досліджень.

Зв'язок з науковими програмами, планами, темами. Дана робота виконувалась відповідно до плану науково-дослідної теми «Медикобіологічне забезпечення фрізичної реабілітації, спортивних та оздоровчих тренувань» (номер держреєстрації 0113U007653) кафедри фрізичної реабілітації, спортивної медицини та валеології Д3 «Дніпропетровська медична академія МО3 України».
Мета дослідження - оцінка фрункціонального стану спортсменів, виявлення напруження адаптаційних механізмів, яке $є$ проявом можливого переходу в наступну фразу - фразу виснаження і фрормування у спортсменів патологічних станів та захворювань, а також своєчасного проведення корекції.

Матеріали і методи дослідження. Всього обстежено 197 спортсменів у віці від 14 до 25 років, які займаються спортом не менше 5 років, у тому числі чоловіків - $132(67,0 \%)$, жінок $65(35,0 \%)$. Усі спортсмени мали спортивну кваліфікацію від першорозрядників до МСМК. До обстеженої групи входили спортсмени циклічних, ациклічних та ігрових видів спорту. До контрольної групи увійшли 20 осіб такого ж віку, практично здорових, які не займаються спортом. Комплексне обстеження включало загальноклінічне обстеження і такі дослідження за стандартними методиками: психологічне (тест Спілбергера), інструментальне (ЕКГ у стані спокою та після фрізичного навантаження) та лабораторне (біохімічні - рівень АТФ еритроцитів, глюкози крові, лактатдегідрогенази (ЛДГ), вміст сироваткового заліза, активність системи перекисного окислення ліпідів (ПОЛ) та антиоксидантного захисту (АОЗ); імунологічні - рівні $\lg$ A, M, G, E, вміст B- і Т-лімфоцитів з визначенням їх субпопуляцій (CD4+, CD8+, CD16+), piвень основних прозапальних інтерлейкінів (IЛ-1, $2,6,8)$, фрактора некрозу пухлин (ФНП- $\alpha)$ i piвень протизапальних інтерлейкінів (IЛ-4, 10). ЕКГ-дослідження проводили 3 використанням автоматизованого діагностичного комплексу «Кардіо+» НПП «Метекол», м. Ніжин, який має державну реєстрацію за № 717/99 від 15.06.1998 р. Після дослідження показників у стані спокою пацієнти виконували вправи з навантаженням (тест PWC ${ }_{170}$ ) на вертикальному велоергометрі «Ketler X1». Тест PWC ${ }_{170}$ на велоергометрі проводили за стандартною методикою для визначення фрізичної працездатності спортсменів [10]. Спостереження проводилися в підготовчому періоді за умови добровільної інфоромованої згоди.

Статистичну обробку отриманих результатів здійснювали за допомогою пакету ліцензійних прикладних програм STATISTICA (6.1, серійний номер AGAR909E415822FA). Пороговим рівнем статистичної значущості отриманих результатів було взято $p<0,05$ [11].

Робота проводилася з дотриманням нормативних документів комісії з медичної етики, розроблених 3 урахуванням положень Конвенції Ради Європи «Про захист прав гідності людини 
в аспекті біомедицини» (1997) та Гельсінкської декларації Всесвітньої медичної асоціації «Етичні принципи медичних досліджень за участю людини у якості об'єкта дослідження» (2008).

Результати дослідження та їх обговорення. Під час проведення досліджень спортсмени в ході клінічного обстеження скарг не висували та в повному обсязі виконували тренувальні навантаження, проте у них було виявлено напруження адаптаційних механізмів. Це виражалося у високому рівні ситуаційної та особистої тривожності (20,6 і 25,9 \% спортсменів відповідно), високому інфрекційному індексі (наявність повторних захворювань ГРВІ три рази на рік і більше - у 16,2 \%), ускладненому перебігу ГРВІ (гайморит, тонзиліт - у 15,7 \%), відсутності поліпшення спортивних результатів упродовж року, що також $є$ одним із критеріїв, який свідчить про напруження адаптаційних механізмів. Серед обстежених нами спортсменів 39,1 \% погіршували спортивні результати.

Якщо поодинокі ознаки ДСТ як генетично детермінований чинник не впливали на адаптацію до значних фрізичних навантажень, то системна недиференційована дисплазія сполучної тканини (наявність 5 ознак і більше), особливо пролапс мітрального клапана (ПМК) II ступеня, поєднувалася з більш вираженим напруженням адаптаційних механізмів, що в свою чергу вимагає частішого спостереження і своєчасного проведення реабілітаційних заходів.

Під час ЕКГ-дослідження зміни, що свідчать про напруження адаптаційних механізмів (тахікардія у стані спокою в поєднанні з відносно високим зубцем $T$, або скороченим інтервалом $Q-T$, або низьким сумарним вольтажем зубців $R$; виражена гіпертрофрія міокарда (ГМ)), констатували у $13,8 \%$ спортсменів, а після навантаження - у 20,8\%, що підтверджує необхідність проведення ЕКГ-дослідження не лише до, але й після фрізичного навантаження. У спортсменів, які погіршували результати, ознаки ГМ правого і лівого шлуночків визначалися достовірно частіше, ніж у прогресуючих спортсменів (62,5 і 31,1 \% відповідно, p < 0,05), що може свідчити про те, що ГМ $\epsilon$ морфологічним критерієм напруження адаптаційних механізмів.

За даними варіаційної пульсометрії (ВПМ), симпатикотонічний тип було виявлено у $22,8 \%$, переважно у спортсменів, які погіршували результати. За даними велоергометричного тесту $\mathrm{PWC}_{170}$, про недостатню адаптацію до значних фізичних навантажень свідчив середній і нижче середнього рівень фрізичного стану (РФС). Такі зміни виявлено у 7,0 \% спортсменів, які здебільшого погіршували результати, з ПМК, п'ятьма і більше ознаками ДСТ.

Таким чином, ознаки напруження адаптації, за даними ЕКГ, виявлено у 13,6 \% спортсменів, за даними ВПМ, - у $22,8 \%$, за даними тесту $\mathrm{PWC}_{170},-$ у $7,0 \%$, хоча спортивні результати протягом року погіршували 39,1 \%. Це підтверджує думку про те, що для оцінювання адаптаційних можливостей спортсменів і своєчасного проведення корекції слід використовувати не лише дані ЕКГ, ВПМ та ергометрії, але й дані біохімічного та імунологічного досліджень.

У всіх спортсменів виявлено модисрікацію метаболізму, що проявлялося зниженням рівня АТФ еритроцитів на тлі нормального вмісту сироваткового фоосфору. Хоча в усіх спортсменів рівні еритроцитів та гемоглобіну були в нормі, вміст сироваткового заліза у них мав виражену тенденцію до зниження (15,3 $\pm 2,5$ ммоль: ${ }^{-1}$, p > 0,05). У спортсменів з ознаками напруження адаптації зниження концентрації сироваткового заліза було статистично достовірним (нижче 14,0 ммоль: $\left.{ }^{-1}\right)$.

Крім фоссрору, АТФ еритроцитів, заліза сироватки крові, непрямим показником стану енергозабезпечення у спортсменів можуть бути такі показники, як вміст глюкози крові та ЛДГ, які відіграють важливу роль у процесі утилізації лактату, що утворюється у значних кількостях під час виконання фрізичних навантажень. У спортсменів виявлено недостовірне зниження рівня глюкози при достовірному зниженні ЛДГ. При цьому у спортсменів 3 ознаками напруження адаптаційних механізмів рівень глюкози був достовірно нижчим, ніж у цілому по групі, хоча залишався в межах норми. Рівень ЛДГ у цих групах не відрізнявся.

У разі напруження адаптаційних механізмів у спортсменів була наявна більш виражена активація ПОЛ з підвищенням рівня малонового діальдегіду (МДА) в 4,5 раза (вища за 16 мкмоль ${ }^{-1}$, що виявлено у $14,1 \%$ ), тоді як у спортсменів 3 доброю адаптацією рівень МДА підвищувався не більше ніж у 3,6 раза. У спортсменів 3 напруженням адаптації також виявлено дисбаланс активності ПОЛ і АОЗ, що проявлялося зниженням коефіцієнта каталаза/МДА більше ніж у 4 рази, у зниженні рівня вітаміну Е (на 40,8 \%), рівня AOA (на $38,0 \%$ ) (р < 0,05). Після одноразового фрізичного навантаження у цих спортсменів виявляли більш виражене накопичення проміжних продуктів ПОЛ (дієнових кон'югатів, або ДК), що мають виражену мембранодестабілізуючу активність, які в свою чергу можуть спричинити розвиток оксидативного стресу. Виражена активація 
ПОЛ також може бути одним із критеріїв напруження адаптаційних механізмів.

Інші біохімічні показники, які широко використовуються в клінічній практиці, при напруженні адаптації у спортсменів достовірно змінені не були.

Тривалі і великі фрізичні навантаження у кваліфікованих спортсменів разом із метаболічними порушеннями можуть призводити до певної модифрікації імунного статусу, особливо в разі зриву адаптаційних механізмів. У спортсменів виявлено підвищення рівня прозапальних інтерлейкінів ІЛ-2, ІЛ-8, ФНП- $\alpha$ на тлі зростання вмісту протизапальних інтерлейкінів ІЛ-4, ІЛ-10. Дуже виражено був підвищений рівень регуляторного ІЛ-2 (у 4,8 раза). Водночас рівні ІЛ-1 і ІЛ-6, що запускають системні реакції гострої фази запалення, у спортсменів не відрізнялися від показників контрольної групи. Підвищення рівня прозапальних інтерлейкінів ІЛ-2, ІЛ-8, ФНП- $\alpha$ у спортсменів вірогідно пригнічувалося у зв'язку з підвищенням вмісту протизапальних інтерлейкінів ІЛ-4, ІЛ-10. Модиорікація імунного статусу в разі напруження адаптаційних механізмів характеризувалася підвищенням рівня $\lg \mathrm{E}\left(53,5 \pm 5,1 \mathrm{MO} \cdot \mathrm{Mл}^{-1}\right)$, рівня CD16+ понад $10,0 \%$ на фоні зниження абсолютної кількості Т-хелперів $(0,38 \pm 0,04)$ і В-лімфоцитів, що може свідчити про певний імунодефріцит на тлі фрізичних навантажень.

Для корекції напруження адаптаційних механізмів всі обстежені спортсмени, незалежно від динаміки спортивних результатів, отримували планову фрармакологічну підтримку два рази на рік (восени і навесні), яка включала курс вітамінотерапії та вживання кардіопротекторів. Вітамінотерапія проводилася комплексним препаратом «Дуовіт» (по 1 таблетці 2 рази на добу), який містить мікроелементи. Тривалість курсу вітамінотерапії залежала від наявності/відсутності критеріїв напруження адаптації. Спортсмени з доброю адаптацією отримували вітаміни впродовж 3 тиж., спортсмени 3 напруженням адаптаційних механізмів - 4 тиж. і додатково адаптогени. Крім вітамінотерапії всі спортсмени 2 рази на рік отримували рибоксин (по 1 таблетці 3 рази на добу) або інозин з кардіопротекторною та метаболічною

\section{Література}

1. АхметоВ И. И. Молекулярная генетика спорта / И. И. Ахметов. - М. : Сов. спорт, 2009. - 268 с.

2. Виноградов В. Е. Изменение фризиологической реактивности кардиореспираторной системы на сдвиги дыхательного гомеостазиса при применении комплекса средств предварительной стимуляции работоспособности / В. Е. Виноградов, Е. Н. Лысенко / / Спорт. медицина. - 2005, № 1. - С. 35-41. дією протягом 4 тиж. Спортсменам 3 напруженням адаптаційних механізмів додатково призначали АТФ-лонг і кардонат; також до комплексу планової реабілітації включили «Тріовіт» з групи антиоксидантів (по 1 капсулі на добу) упродовж 4 тиж. у зв'язку з тим, що внаслідок виконання значних фрізичних навантажень відзначалася активація ПОЛ на тлі активації окремих показників АОЗ. Антиоксиданти гальмують токсичні ефекти вільно-радикального окислення, сприяють нейтралізації негативних впливів окислення на організм та підвищенню витривалості в умовах значних фрізичних навантажень. Спортсменам, у яких було виявлено зниження кількості еритроцитів, рівня гемоглобіну в загальному аналізі крові або зниження рівня сироваткового заліза менше 14,0 ммоль"л ${ }^{-1}$, до курсу планової терапії включали препарат заліза «Глобірон» (по 1 таблетці на день) протягом 3-4 тиж.

Застосування планової реабілітаційної терапії дозволило покращити стан здоров'я спортсменів, сприяло достовірному зниженню частоти захворювань, а також зменшенню кількості пропусків (у зв'язку з хворобою) тренувальних днів. Крім того, застосування запропонованої планової реабілітації дало можливість поліпшити адаптацію спортсменів до тренувальних навантажень, що забезпечило позитивну динаміку спортивних результатів.

\section{Висновки.}

У роботі доведено необхідність урахування критеріїв напруження адаптаційних механізмів для своєчасного призначення реабілітаційних заходів у кваліфікованих спортсменів.

Запропоновано планову фармакологічну підтримку, яка дозволила поліпшити стан здоров'я спортсменів, сприяла зниженню частоти захворюваності, тривалості захворювань і пропусків тренувальних днів, що забезпечило планомірну, якісну підготовку спортсменів до успішних виступів на змаганнях.

Перспективи подальших досліджень полягають у розробленні, науковому обгрунтуванні та впровадженні в практику алгоритму обстеження і вибору схем реабілітації у кваліфрікованих спортсменів з урахуванням їх адаптаційних можливостей.

\section{References}

1. Ahmetov I. I. (2009) Molekulyarnaya genetika sporta [Molecular genetics of sport]. M.: Sovetskij sport. (in Russian)

2. Vinogradov V. E., Lysenko E. N. (2005) Izmenenie fiziologicheskoy reaktivnosti kardiorespiratornoy sistemy na sdvigi dykhatelnogo gomeostazisa pri primenenii kompleksa sredstv predvaritelnoy stimulyatsii rabotosposobnosti [Changing physiological reactivity cardiorespiratory system shifts respiratory ho- 
3. ДорофьєєВа О. Є. Напруження адаптційних механізмів у спортменів високого класу та його корекція / О. Є. Дорофрєєва / / Вісн. пробл. біології і медицини. - 2016. - Т. 1 (126), вип. 1. - С. 332-336.

4. Дроздовская С. Б. О возможности применения молекулярно-генетических методов в оздоровительном фитнесе / С. Б. Дроздовская, Е. В. Андреева, О. А. Боровик // Спорт. медицина. - 2012. - № 1. - С. 102-109.

5. Лысенко E. Особенности фрункциональных возможностей гребцов на байдарках и каноэ высокой квалисрикации / Е. Лысенко, О. Шинкарук, В. Самуйленко, Г. Россоха, Н. Спичак // Наука в олимп. спорте. - 2004. № 2. - С. 65-71.

6. Макарова Г. А. Спортивная медицина : учебник / Г. А. Макарова. - М. : Сов. спорт, 2003. - 480 с.

7. НеханеВич О. Б. Цілеспрямований скринінг для профрілактики серцево-судинних ускладнень в спорті та оздоровчій фізичній культурі / О. Б. Неханевич // Вісн. пробл. біології і медицини. - 2015. - Т. 4 (121), вип. 1. - С. 285-289.

8. НеханеВич О. Б. Особливості лікарського контролю за спортсменами з ознаками дисплазії сполучної тканини / О. Б. Неханевич, О. Є. Дорофрєєва, О. Л. Смирнова, В. В. Логвиненко // Вісн. пробл. біології і медицини. 2015. - T. 2 (125), вип. 4. - С. 323-327.

9. Уилмор Дж. Х. Физиология спорта : пер. с англ. / Дж. Х. Уилмор, Д. Л. Костилл. - К. : Олимп. лит., 2001. $502 \mathrm{c}$.

10. Фізична реабілітація, спортивна медицина / В. В. Абрамов, В. В. Клапчук, О. Б. Неханевич [та ін.]; за ред. В. В. Абрамова та О. Л. Смирнової. - Дніпропетровськ : Журфонд, 2014. - 455 с.

11. Халафян А. A. STATISTICA 6. Статистический анализ данных / А. А. Халафян. - М. : ООО «Бином-Пресс», 2007. -512 c.

12. Basso C. Arrhythmogenic right ventricular cardiomyopathy / C. Basso, D. Corrado, F. I. Marcus [et al.] // Lancet. - 2009. - Vol. 373, N 11. - P. 1289-1300.

13. Bille K. Sudden cardiac death in athletes: the Lausanne Recommendations / K. Bille, D. Figueiras, P. Schamasch [et al.] / / Eur. J. Cardiovasc. Prev. Rehabil. - 2006. - Vol. 13, N 6. - P. 859-875.

14. Bray M. S. The human gene map for performance and health-related fitness phenotypes: the 2006-2007 update / M. S. Bray, J. M. Hamberg, L. Perrusse [et al.] // Med. Sci. Sports Exercise. - 2009. - Vol. 41, N 1. - P. 35-73.

15. Holst $A$. G. Incidence and etiology of sports-related sudden cardiac death in Denmark-implications for preparticipation screening / A. G. Holst, B. G. Winkel, J. Theilade / / Forensic Sci. Int. - 2009. - Vol. 30, N 6. - P. 7-11.

16. Maron B. J. The Heart of trained athletes: cardiac remodeling and the risks of sports, including sudden death / B. J. Maron, A. Pelliccia / / Circulation. - 2006. - Vol. 114, N 15. - P. 1633-1644.

17. Schmied C. Sudden cardiac death in athletes/ C. Schmied, M. Borjesson // J. Intern. Med. - 2014. Vol. 275, N 2. - P. 93-103.

18. Solberg E. E. Sudden death in sports among young adults in Norway / E. E. Solberg, F. Gjertsen, E. Haugstad, L. Kolsrud // Eur. J. Cardiovasc. Prev. Rehabil. - 2010. Vol. 17, N 3. - P. 337-341.

19. Tanskanen $M$. Altered oxidative stress in overtrained athletes / M. Tanskanen, M. Atalay, A. Uusitalo // J. Sports Sci. - 2010. - Vol. 28, N 3. - P. 309-317.

dorofeyevaelena@mail.ru meostasis in the application of the complex pre-stimulation efficiency funds]. Sportivna meditsina, no 1, pp. 35-41. (in Russian)

3. Dorofeєva O. E. (2016) Napruzhennya adaptacijnih mekhanizmiv u sportsmeniv visokogo klasu ta jogo korekciya [Tension of adaptation mechanisms in elite athletes and its correction]. Visnik problem biologii i medicine, vol. 1 (126), pp. 332-336. (in Ukrainian)

4. Drozdovskaya S. B., Andreeva E. V., Borovik O. A. (2012) O vozmozhnosti primeneniya molekulyarno-geneticheskih metodov $v$ ozdorovitel'nom fitnese [On application of molecular-and-genetic methods in health related fitness]. Sportivna medicina, no 1, pp. 102-109. (in Russian)

5. Lysenko Ye., Shinkaruk O., Samuylenko V., Rossokha G., Spichak N. (2004) Osobennosti funktsionalnykh vozmozhnostey grebtsov na baydarkakh i kanoe vysokoy kvalifikatsii [Types of respiratory system physiological reactivity and specifics of athlete special work capacity manifesrations]. Nauka $v$ olimpiyskom sporte, no 2, pp. 65-71. (in Russian)

6. Makarova G. A. (2003) Sportivnaya medicina: Uchebnik [Sports medicine: textbook]. M.: Sovetskij sport. (in Russian)

7. Nekhanevich O. B. (2015) Cilespryamovanij skrining dlya profilaktiki sercevo-sudinnih uskladnen' $v$ sporti ta ozdorovchij fizichnij kul'turi [Purposeful screening for cardiovascular complication prevention in sport and physical culture]. Visnik problem biologii i medicine, Vip. 2., vol. 4 (121), pp. 285-289. (in Ukrainian)

8. Nekhanevich O. B., Dorof $\epsilon € v a$ O. $€$., Smirnova O. L., Logvinenko V. V. (2015) Osoblivosti likars'kogo kontrolyu za sportsmenami z oznakami displaziï spoluchnoï tkanini $[\mathrm{Pe}-$ culiarities of medical control for athletes with signs of connective tissue dysplasia]. Visnik problem biologii i medicine, vol. 2 (125), vip. 4, pp. 323-327. (in Ukrainian)

9. Uilmor Dzh. H., Kostill D. L. (2001) Fiziologiya sporto [Physiology of sport]: per. s angl. K. : Olimp. lit. (in Russian)

10. Abramov V. V., Klapchuk V. V., Nekhanevich O. B. (2014) Fizichna reabilitaciya, sportivna medicina [Physical rehabilitation, sports medicine]. Dnipropetrovs'k: ZHurfond. (in Ukrainian)

11. Halafyan A. A. (2007) STATISTICA 6. Statisticheskij analiz dannyh [STATISTICA 6. Data statistical analysis]. M.: 000 «Binom-Press». (in Russian)

12. Basso C., Corrado D., Marcus F. I. (2009) Arrhythmogenic right ventricular cardiomyopathy. Lancet, vol. 373, no 11, pp. 1289-1300.

13. Bille K., Figueiras D., Schamasch P. (2006) Sudden cardiac death in athletes: the Lausanne Recommendations. Eur. J. Cardiovasc. Prev. Rehabil., vol. 13, no 6, pp. 859-875.

14. Bray M. S., Hamberg J. M., Perrusse L. (2009) The human gene map for performance and health-related fitness phenotypes: the 2006-2007 update. Med. Sci. Sports Exercise, vol. 41 , no 1 , pp. $35-73$.

15. Holst A. G., Winkel B. G., Theilade J. (2009) Incidence and etiology of sports-related sudden cardiac death in Denmark-implications for preparticipation screening. Forensic Sci. Int., vol. 30, no 6, pp. 7-11.

16. Maron B. J., Pelliccia A. (2006) The Heart of trained athletes: cardiac remodeling and the risks of sports, including sudden death. Circulation, vol. 114, no 15, pp. 1633-1644.

17. Schmied C., Borjesson M. (2014) Sudden cardiac death in athletes, J. Intern. Med., vol. 275, no 2, pp. 93-103.

18. Solberg E. E., Gjertsen F., Haugstad E., Kolsrud L. (2010) Sudden death in sports among young adults in Norway. Eur. J. Cardiovasc. Prev. Rehabi., vol. 17, no 3, pp. 337-341.

19. Tanskanen M., Atalay M., Uusitalo A. (2010) Altered oxidative stress in overtrained athletes. J. Sports Sci., vol. 28, no 3, pp. 309-317.

Надійщла 22 04.2016 